\title{
Efficiency of food conversion and body composition of the preruminant lamb and the young pig
}

\author{
BY R. W. HODGE* \\ Department of Animal Production, School of Agriculture, \\ University of Melbourne, Parkville, Victoria 3052, Australia \\ (Received 23 Fuly I973-Accepted I I December I973)
}

\begin{abstract}
1. A comparison was made of the efficiency of food conversion and body composition of the preruminant lamb and young pig when offered cow's milk supplemented with minerals and vitamins from 2 to ro weeks of age.

2. The daily voluntary intake of gross energy $/ \mathrm{kg}$ live weight $\mathrm{t}^{0 \cdot 75}$ of the pigs was significantly greater than that of the lambs. The daily voluntary intake of the lambs decreased from 1895 to $1573 \mathrm{~kJ} / \mathrm{kg}$ live weight $0^{0.75}\left(453\right.$ to $376 \mathrm{kcal} / \mathrm{kg}^{0.75}$ ) over the experimental period and that for the pigs increased from 2063 to $2519 \mathrm{~kJ} / \mathrm{kg}$ live weight ${ }^{0.75}\left(493\right.$ to $\left.602 \mathrm{kcal} / \mathrm{kg}^{0.75}\right)$.

3. Of the organic matter of the milk, $0.97-0.98$ was digested by both species. Food conversion ratio ( $\mathrm{kg}$ dry matter milk/kg live-weight gain) did not differ between the species when food was given ad lib. but pigs restricted to $80 \%$ of voluntary food intake or to $1255 \mathrm{~kJ} / \mathrm{kg}$ live weight $\mathrm{t}^{0.75}\left(300 \mathrm{kcal} / \mathrm{kg}^{0 \cdot 75}\right)$ had a lower food conversion ratio than lambs similarly restricted in intake.

4. A $20 \%$ reduction in the voluntary intake of gross energy decreased daily protein deposition in the lambs only but decreased daily fat deposition in both species.
\end{abstract}

There appears to be only one comparative study of sheep and pigs given the same diet (Meyer \& Nelson, 1963). From their results it can be calculated that, with a low-fibre diet, the energy and nitrogen retained by pigs were 14 and $7 \%$ greater respectively than those of sheep. These results were supported by Blaxter (1968), who calculated that, with cereal diets, the theoretical maximum retention of energy was $15 \%$ greater by pigs than by ruminants. The differences may be attributed, in part, to the energy and protein losses associated with microbial fermentation compared with digestion by mammalian enzymes only. However, there appears to be no information on the comparative efficiency of food utilization by the young pig and the preruminant lamb.

The object of the studies reported here was to compare the nutritional efficiencies of the young lamb and pig when each was fed on reconstituted whole cow's milk supplemented with minerals and vitamins. Nutritional efficiency was examined in terms of the voluntary intake of energy and the ratios of food consumed: live weight, $\mathrm{N}$ and energy gain. These indices of efficiency were examined between about 6 and $70 \mathrm{~d}$ of age when the milk diet was given: (a) $a d l i b . ;(b)$ at $80 \%$ of the $a d l i b$. intake; $(c)$ at equal levels of energy intake/kg live weight ${ }^{0 \cdot 75}$.

* Present address: S. S. Cameron Laboratory, State Research Farm, Werribee, Victoria 3030, Australia. 


\section{MATERIALS AND METHODS}

\section{General details}

Two experiments were done. In Expt I fifteen male lambs and fifteen male pigs were removed from their dams at $3-4 \mathrm{~d}$ of age and given a reconstituted whole-milk diet ad lib. At 10-1 $5 \mathrm{~d}$ of age, when they had reached specified live weights, three animals of each species were taken at random and slaughtered. Twelve of the remaining animals (six of each species) were given the milk diet $a d$ lib. and twelve (six of each species) were given the same diet at $80 \%$ of the ad lib. levels. Six of the lambs and six of the pigs (three animals fed $a d l i b$. and three restricted in intake) were slaughtered at 5 weeks, and the same number at 8 weeks of age when they had reached specified live weights.

In Expt 2, eight male lambs and eight male pigs were weaned at between 2 and $4 \mathrm{~d}$ of age and given a diet similar to that given in Expt $\mathrm{r}$. The animals were fed ad lib. until $\mathrm{r} 6 \mathrm{~d}$ of age when four lambs and four pigs were slaughtered. The remaining animals were given the milk diet at the same level of energy intake/kg live weight ${ }^{0.75}$, until they were slaughtered at specified live weights at about no weeks of age.

\section{Animals}

The piglets in both experiments were obtained from a Large White minimal disease herd and were placed in individual pens $(0.6 \mathrm{r} \times 0.9 \mathrm{I} \times 0.46 \mathrm{~m})$ heated by infrared lamps; the piglets were not castrated.

The lambs were (Border Leicester $\delta \times$ Merino ㅇ) $ᄋ \times$ Dorset Horn $\delta$, different flocks supplying the lambs for the two experiments. The animals were placed in the same metabolism room as the pigs and confined in similar individual pens. The lambs were not castrated but their tails were fitted with rubber rings and cut off below the ring. Each lamb was vaccinated against disease (enterotoxaemia, blackleg, malignant oedema, tetanus and black disease) with a multi-dose vaccine (TVL vaccine; Tasman Vaccine Laboratory (Aust.) Pty Ltd, Victoria, Australia) at 4 and $20 \mathrm{~d}$ of age.

\section{Diet and feeding}

The diet used in Expts $\mathrm{I}$ and 2 was cow's dried whole-milk powder reconstituted with water at a rate of $200 \mathrm{~g}$ dry matter $/ \mathrm{kg}$. Minerals and vitamins were added to the reconstituted milk as shown in Table $\mathrm{I}$. The mineral and vitamin additives were based on the Agricultural Research Council recommendations for ruminants (Agricultural Research Council, 1965) and for pigs (Agricultural Research Council, 1967). Whenever the recommendations differed between the species the higher value was adopted.

The ration was prepared every and or $3^{\text {rd }}$ day and cooled overnight to $4^{\circ}$, and offered at that temperature usually $\mathrm{I} d$ later. The vitamin supplement was added to each mix just before feeding. The amounts of milk offered to the animals fed ad lib. were adjusted to maintain the residues at $15-20 \%$ of the fresh weight consumed.

Milk samples (approximately ı०o g) were taken from each mix before feeding, 
Table I. Minerals and vitamins added to reconstituted dried milk diet given to lambs and pigs in Expts I and 2 (/kg dry matter)

\begin{tabular}{lc}
\multicolumn{2}{c}{ Minerals } \\
$\mathrm{MgSO}_{4} \cdot 7 \mathrm{H}_{2} \mathrm{O}$ & $\mathrm{I} 0 \mathrm{~g}$ \\
$\mathrm{Mineral}_{\mathrm{mix}}$ to give $(\mathrm{mg} / \mathrm{kg}$ dry matter $):^{*}$ & \\
$\mathrm{FeSO}_{4} \cdot 7 \mathrm{H}_{2} \mathrm{O}$ & 1000 \\
$\mathrm{MnSO}_{4} \cdot 4 \mathrm{H}_{2} \mathrm{O}$ & 170 \\
$\mathrm{ZnCl}_{2}$ & 160 \\
$\mathrm{CuSO}_{4} \cdot 5 \mathrm{H}_{2} \mathrm{O}$ & $\mathrm{I} 3$ \\
$\mathrm{KI}$ & $\mathrm{I} \cdot 3$ \\
$\mathrm{CoCl}_{2} \cdot 6 \mathrm{H}_{2} \mathrm{O}$ & 0.4
\end{tabular}

\begin{tabular}{lr}
\multicolumn{2}{c}{ Vitamins } \\
Choline chloride & $2.66 \mathrm{~g}$ \\
myo-Inositol & $0.20 \mathrm{~g}$ \\
Ascorbic acid & $0.10 \mathrm{~g}$ \\
p-Aminobenzoic acid & $0.02 \mathrm{~g}$ \\
Vitamin mix: & \\
Retinol & $540 \mu \mathrm{g}$ \\
Cholecalciferol & $188 \mu \mathrm{g}$ \\
Menaphthone & $80 \mathrm{mg}$ \\
Nicotinamide & $2.5 \mathrm{mg}$ \\
Pantothenic acid & $2.5 \mathrm{mg}$ \\
a-Tocopherol & $2.0 \mathrm{mg}$ \\
Cyanocobalamin & $2.0 \mathrm{mg}$ \\
Thiamin & $1.0 \mathrm{mg}$ \\
Riboflavin & $0.5 \mathrm{mg}$ \\
Pyridoxine & $0.3 \mathrm{mg}$
\end{tabular}

* The mineral mix was made up in water as follows $(\mathrm{g} / 1): \mathrm{FeSO}_{4} \cdot 7 \mathrm{H}_{2} \mathrm{O}, 60 \cdot 0 ; \mathrm{MnSO}_{4} \cdot 4 \mathrm{H}_{2} \mathrm{O}, 10 \cdot 0$; $\mathrm{ZnCl}_{2}, 9 \cdot 3 ; \mathrm{CuSO}_{4} \cdot 5 \mathrm{H}_{2} \mathrm{O}, 0.8 ; \mathrm{KI}, 0.08 ; \mathrm{CoCl}_{2} .6 \mathrm{H}_{2} \mathrm{O}, 0.024$.

bulked over ten mixes and freeze-dried. Milk residues were sampled daily, bulked over Io $\mathrm{d}$ periods and freeze-dried.

The pigs and lambs were taught to drink the milk ration initially from babies' feeding-bottles and later from plastic containers (fitted with rubber teats) situated at the front of each pen. In Expt I milk was available for $23 \mathrm{~h}$ each day to those animals fed $a d$ lib.

In Expt 2 the lambs and pigs were offered, from $16 \mathrm{~d}$ of age, their daily ration in four equal feeds spaced evenly between 08.00 and 20.00 hours; this was reduced to three feeds daily when the animals reached $35 \mathrm{~d}$ of age.

\section{Allotment of animals}

Expt I. The voluntary intakes of the lambs and pigs were recorded from 6 to ro d of age, the animals being arranged in order of voluntary intake $/ \mathrm{kg}$ live weight $\mathrm{t}^{0.75}$ and allotted at random to an initial slaughter group, a ' $30^{\prime}$ ' $\mathrm{d}$ group and a ' $50^{\prime}$ ' $\mathrm{d}$ group. Animals within the ' 30 ' or ' 50 ' groups were further allotted at random to subgroups in which they were either fed ad lib. or given an amount restricted to $80 \%$ of the $a d$ lib. intake. The lambs and pigs in the initial slaughter group were killed when they reached 7.5 and $3.8 \mathrm{~kg}$ live weight respectively. The lambs in the ' 30 ' and ' 50 ' group were slaughtered at 17 and $27 \mathrm{~kg}$ live weight respectively and the pigs in the corresponding groups at $\mathrm{I}_{5}$ and $33 \mathrm{~kg}$ live weight. These live weights were determined by the heaviest animal of each species which was slaughtered at 10, 30 or $50 \mathrm{~d}$ of age. The groups are hereafter referred to as the ' 10 ', ' 30 ' or ' 50 ' $\mathrm{d}$ groups.

Expt 2. At I4 $^{-1} 5 \mathrm{~d}$ of age the animals were arranged in order of live weight and allotted at random to either an initial slaughter group or a group fed on milk at the rate of $1255 \mathrm{~kJ}(300 \mathrm{kcal}) / \mathrm{kg}$ live weight ${ }^{0.75}$. The animals in the initial slaughter group 
were killed at $\mathrm{r} 6 \mathrm{~d}$ of age. In the other group the lambs and pigs were killed at about $70 \mathrm{~d}$ of age when they had reached 32 and $26 \mathrm{~kg}$ live weight respectively.

\section{Live weight}

In Expt I the animals were weighed daily between 09.00 and ro.00 hours. In Expt 2 they were weighed on alternate days.

\section{Voluntary food intake}

The relationship between the voluntary intake of milk energy $(\mathrm{kJ} / \mathrm{d})$ and metabolic live weight $\left(\mathrm{kg}^{0 \cdot 25}\right)$ for the lambs and pigs was determined by regression analysis. The mean voluntary intake of each animal in Expt $\mathrm{I}$ was calculated over a 4 or $5 \mathrm{~d}$ period from a mean age of $5^{-6} \mathrm{~d}$ until slaughter. The corresponding mean live weight for each animal was calculated as the arithmetic mean of the daily weight taken over each $4^{-5} \mathrm{~d}$ period (allowing a $24 \mathrm{~h}$ lag between intake and live weight). The regression of intake on metabolic live weight was calculated for each species using all available values from all animals. A stepwise regression programme was used and the final equations included only the significant coefficients $(P<0.05)$. The equations fitted were of the form:

$$
I=a+b W+c W^{2}+d W^{3}
$$

where $I=$ intake $(\mathrm{kJ} / \mathrm{d})$ and $W=$ live weight $\left(\mathrm{kg}^{0 \cdot 75}\right)$. The regression covered the range of metabolic live weight from 5 to I I $\mathrm{kg}$ and from 3 to I $_{3} \mathrm{~kg}$ for lambs and pigs respectively.

\section{Collection of faeces and urine}

Expt $\mathrm{I}$. The faecal and urinary outputs of the animals were measured over two ro d periods when the animals were $20-29 \mathrm{~d}$ old (period I) and when they were $40-59 \mathrm{~d}$ old (period 2).

For pigs the metabolism cages were designed for the separate collection of faeces and urine. The urine was collected in plastic buckets which contained about $100 \mathrm{ml}$ of I M-hydrochloric acid. A sample of $50 \mathrm{ml} / \mathrm{l}$ was taken and bulked in a plastic container over the ro d period. Three ro $\mathrm{ml}$ samples were taken for $\mathrm{N}$ analysis and the remainder was freeze-dried for energy determination.

The faeces were bulked over the ro $d$ period and sampled for determination of moisture, energy, $\mathrm{N}$ and ash.

For lambs the collection, storage and treatment of urine were the same as for the pigs, but harnesses made of light plastic and cotton tapes were fitted to the lambs to collect faeces. The faeces were bulked over the ro $d$ period and sampled and analysed as for the pig faeces.

Expt 2. The faeces and urine output of the lambs and pigs was again measured over two ro d periods - when the animals were 25-34 d old (period $\mathrm{r}$ ) and when they were 55-64 d old (period 2). The methods of collection and sampling of the urine and faeces were the same as those used in Expt I. Moisture, energy, $\mathrm{N}$ and ash content were determined in the faeces and energy and $\mathrm{N}$ content in the urine. 


\section{Procedure at slaughter}

Expt I. When the animals of the various groups had reached their specified live weights they were fasted for $18 \mathrm{~h}$ and then offered milk $a d l i b$. for $30 \mathrm{~min}$. They were anaesthetized $2 \mathrm{~h}$ later by an intravenous injection of sodium pentobarbitone; the jugular vein was severed and the blood collected in bins which contained approximately I $g$ potassium oxalate/l blood. The oesophagus was tied off, the thorax and abdomen were opened and the stomach was tied at the pyloric-duodenal junction. In the lambs the abomasum was tied at the omasal-abomasal junction. The stomach (or abomasum) was removed from the rest of the alimentary tract and weighed, together with its contents. The contents were transferred to plastic containers and stored at $-15^{\circ}$. The remainder of the alimentary tract - the oesophagus, the small intestine, the caecum and the large intestine (including the colon and rectum)-were emptied of their contents, stripped of fat and, together with the empty abomasum and stomach, were weighed. The alimentary tract as a whole was placed in a sealed plastic bag, weighed and stored at $-15^{\circ}$.

The 'offal' was removed from the body cavity. This comprised the tongue, trachea and lungs, heart, liver, spleen, pancreas, diaphragm, emptied bladder and gall-bladder, reproductive organs, omental, mesenteric and perinephric fat, connective tissue and superficial blood vessels. The heart, liver, spleen and pancreas were weighed and stored at $-15^{\circ}$. The eviscerated carcass, which included the kidneys, head, feet, skin and (for the pigs) hair was placed in a polyethylene bag, weighed and stored at $-15^{\circ}$. Two samples of blood, each of 100-1 $50 \mathrm{~g}$, were taken: one was dried at $100^{\circ}$ for $48 \mathrm{~h}$ and the other freeze-dried for 5-7 d. With the lambs, all wool was clipped from the necks of the animals before slaughter and the pelts were removed from the carcasses after slaughter. The fresh weight of each pelt was recorded, and two longitudinal strips, approximately $25 \mathrm{~mm}$ wide, were cut down the entire length of the pelt. These were cut into lengths of about $25 \mathrm{~mm}$ and bulked. Half (approximately $3 \circ \mathrm{g}$ ) was dried at $100^{\circ}$ for $48 \mathrm{~h}$ and the remainder stored in air-tight jars at $-15^{\circ}$.

Expt 2. The procedure at slaughter and storage of the carcass, alimentary tract, 'offal', blood and pelt (from the lambs) was identical to that in Expt r. However, the animals were not given a test meal before slaughter and the contents of the abomasum or stomach were not collected.

\section{Preparation of carcass, alimentary canal and offal for analysis}

The carcasses were removed from storage and, while still frozen, were cut into cubes with a band-saw. The cubed material was returned to the polyethylene storage bags and allowed to thaw. It was then ground through a die with holes of $9 \mathrm{~mm}$ diameter, mixed and six samples were taken. Two of these were dried at $100^{\circ}$ for $48 \mathrm{~h}$, two were freeze-dried for $5-7 \mathrm{~d}$ and two were stored at $-15^{\circ}$. The preparation and sampling of the alimentary tract and offal of all animals was the same as that used for the carcasses.

The small square pelt samples were frozen in liquid nitrogen, ground through a mill with a screen size of $3 \mathrm{~mm}$ diameter and stored at $-15^{\circ}$. 
Table 2. Expt 1. Mean daily intake of gross energy (/kg live weight $\left.{ }^{0.75}\right)$ by the lambs and pigs fed ad lib.

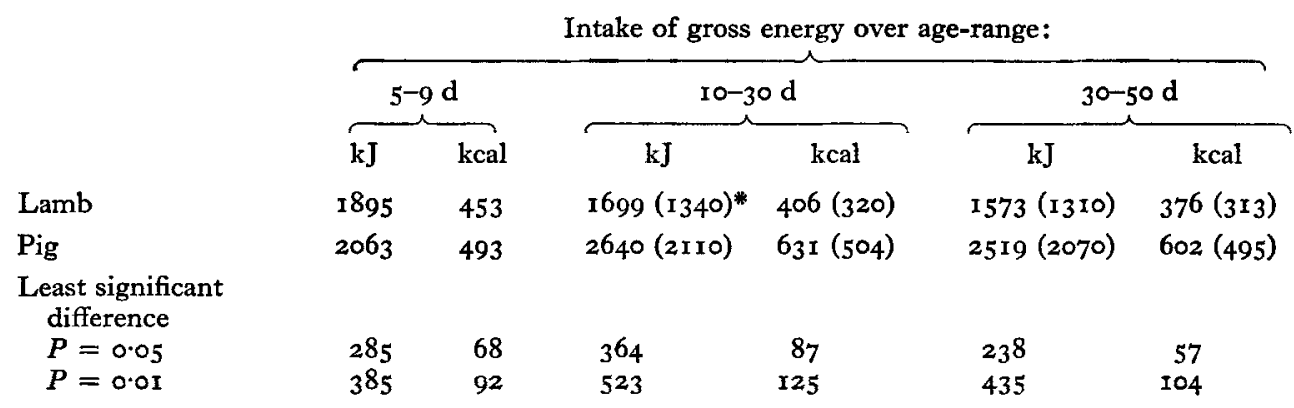

* Figures in parentheses are mean intakes of animals restricted in intake.

Samples of the ground carcasses from four animals of each species in Expt I were analysed for energy content (two from the ' 30 ' d group and two from the ' 50 ' $\mathrm{d}$ group). A total of approximately $20 \mathrm{~g}$ freeze-dried material was refluxed with diethyl ether for $24-28 \mathrm{~h}$. This defatted material, which was assumed to contain only protein and ash, was frozen in liquid nitrogen and ground through a $\mathrm{I} \mathrm{mm}$ screen in a laboratory mill before analysis for energy and ash content. The diethyl ether-extractable material was stored at $-15^{\circ}$ until analysed.

\section{Energy gain}

The total energy content of the lambs or pigs was determined by multiplying the protein and fat contents by the mean values obtained for the energy content of samples of protein and fat taken from the carcasses of the four animals of each species in Expt $\mathrm{I}$.

\section{Chemical analysis}

$\mathrm{N}$ was determined on either fresh or freeze-dried material by the macro-Kjeldahl method with perchloric acid and selenium oxide. Fat was extracted from the freezedried carcass samples in a Soxhlet apparatus with diethyl ether over a period of 24$28 \mathrm{~h}$. Dry matter and ash of all samples were determined by drying at $100^{\circ}$ for $48 \mathrm{~h}$ and at $550^{\circ}$ for $24 \mathrm{~h}$ respectively. Energy was measured in an adiabatic bomb calorimeter.

\section{RESULTS}

Composition of the diets

The mean dry matter of the reconstituted whole milk was $196 \mathrm{~g} / \mathrm{kg}$. In dry matter, the milk contained $290 \mathrm{~g}$ protein $(\mathrm{N} \times 6.38)$, $60 \mathrm{~g}$ ash and $23.64 \mathrm{MJ}(5.65 \mathrm{Mcal})$ gross energy $/ \mathrm{kg}$.

\section{Energy content of protein and fat}

Mean values of $22 \cdot 17$ and $39 \cdot 32 \mathrm{~kJ}(5 \cdot 3$ and $9 \cdot 4 \mathrm{kcal}) / \mathrm{g}$ dry matter were obtained for the protein and fat from the four lamb carcasses and the corresponding values for the pigs were 22.59 and $39.33 \mathrm{~kJ}(5.4$ and $9.4 \mathrm{kcal}) / \mathrm{g}$. 
Table 3. Regression values for voluntary intake $(k \mathfrak{f} / d)$ on live weight $\left(\mathrm{kg}^{0.75}\right)$ of lambs and pigs

Source of variation

Constant

Variable W $\left(\mathrm{kg}^{0 \cdot 75}\right)$

$\mathrm{W}^{2}\left(\mathrm{~kg}^{0 \cdot 75}\right)$

$\mathrm{W}^{8}\left(\mathrm{~kg}^{0 \cdot 75}\right)$

Multiple correlation coefficient $(R)$

Variance of intake accounted for by variables $\left(R^{2}\right)$

\begin{tabular}{|c|c|}
\hline \multicolumn{2}{|c|}{ Regression coefficient } \\
\hline Lambs & Pigs \\
\hline 2206 & -3374 \\
\hline $\begin{array}{c}1348 \pm 88 * \\
\text { NS } \\
\text { NS }\end{array}$ & $\begin{array}{c}3^{6}{ }^{8} \pm 222 * \\
N S \\
-6 \cdot 2 \pm I \cdot I\end{array}$ \\
\hline
\end{tabular}

$0.92 \quad 0.98$

$0.84 \quad 0.96$

NS, not significant.

* Standard error of the mean.

Table 4. Mean apparent digestibility ratios of milk given to lambs and pigs

Lambs

Pigs

Least significance

difference

$P=0.05$

$P=0.01$

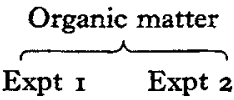

$\overbrace{\text { Expt I }}^{\text {Expt } 2}$

0.974

0.970

0.972

0.980

0.005

0.008

0.008

0.013

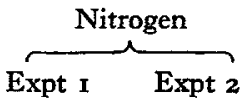

0.952

$0.96 \mathrm{x}$

0.947

0.976 $\begin{array}{ll}0.009 & 0.014 \\ 0.013 & 0.022\end{array}$

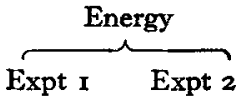

$\begin{array}{ll}0.977 & 0.972\end{array}$

$0.962 \quad 0.983$

$0.006 \quad 0.008$

$0.009 \quad 0.012$

\section{Voluntary intake of energy}

The mean values for the intake of gross energy by the animals fed ad lib. in Expt I are shown in Table 2. There was no significant differences between lambs and pigs in the voluntary intake of energy $/ \mathrm{kg}$ live weight ${ }^{0.75}$ from 5 to $9 \mathrm{~d}$ of age, but the pigs consumed significantly more energy than the lambs $(P<0.0 \mathrm{I})$ from ro to $50 \mathrm{~d}$ of age. The equations obtained for the relationship between the voluntary intake of gross energy $(\mathrm{kJ} / \mathrm{d})$ and metabolic live weight $\left(\mathrm{kg}^{0.75}\right)$ are presented in Table 3 . A linear relationship existed between intake of milk energy and metabolic live weight for the lambs, but the cubic term was also significant for the pigs $(P<0.05)$.

\section{Digestibility}

The apparent digestibility ratios for organic matter, $\mathrm{N}$ and energy of the milk in Expts $\mathrm{I}$ and 2 are shown in Table 4. There were no significant effects due to age or level of feeding in either species and the values presented are means for all animals over the periods when digestibility was measured (from 20 to 29 and from 40 to $49 \mathrm{~d}$ of age in Expt I, and from 25 to 34 and from 55 to $64 \mathrm{~d}$ of age in Expt 2). The digestibility ratios of all components were high in both experiments and there was no evidence of large differences between species. 
Table 5. Metabolizable energy: gross energy ratio of milk given to lambs and pigs

$\begin{array}{lcc} & \text { Expt I } & \text { Expt 2 } \\ \text { Lambs } & 0.918 & 0.908 \\ \text { Pigs } & 0.896 & 0.903 \\ \text { Least significant difference } & & \\ P=0.05 & 0.010 & 0.019 \\ P=0.01 & 0.015 & 0.028\end{array}$

Table 6. Effect of age and level of feeding on retention of digested nitrogen in the empty body of lambs and pigs

Lambs

Pigs

Least significant difference $P=0.05$

$P=0.01$

$\overbrace{\begin{array}{c}\text { ad } l i b . \\ \text { feeding } \begin{array}{c}\text { Restricted } \\ \text { feeding }\end{array}\end{array}}^{\text {Expt I }} \overbrace{\begin{array}{c}\text { ad lib. } \\ \text { feeding } \begin{array}{c}\text { Restricted } \\ \text { feeding }\end{array}\end{array}}^{30-50 \text { d of age }}$

$\underbrace{\begin{array}{lll}0.490 & 0.539 \\ 0.502 & 0.572\end{array}}_{\begin{array}{lll}0.111 \\ 0.162\end{array}} \underbrace{\begin{array}{ll}0.302 & 0.344 \\ 0.086\end{array}}_{\begin{array}{ll}0.056 \\ 0.350\end{array}}$

\section{Metabolizable energy of the milk}

The metabolizable energy of the milk, expressed as a percentage of the gross energy intake, is shown in Table 5. There was no significant effect due to level of food intake or age in Expt $\mathrm{I}$ or to age in Expt 2. The values presented, therefore, are means for all animals and both periods. In Expt $\mathrm{I}$ loss of the gross energy intake in the faeces and urine was significantly smaller $(P<0.01)$ in the lambs than in the pigs, but there was no significant difference between species in Expt 2.

\section{Retention of $N$ and energy}

The fraction of the digested $\mathrm{N}$ intake which was retained in the empty body of the animals is given in Table 6 . Significant differences between species were not found in Expt I but in Expt 2 the fraction of the gross $\mathrm{N}$ intake retained by the pigs was significantly greater $(P<0.01)$ than that retained by the lambs. The mean fraction of $\mathrm{N}$ retained by the pigs restricted in intake in Expt $\mathrm{I}$ was higher throughout than for pigs fed $a d$ lib. but the difference was significant $(P<0.01)$ only in those animals killed at about $50 \mathrm{~d}$ of age. A similar but non-significant trend was noted for the restricted lambs from 10 to $30 \mathrm{~d}$ of age but there was no difference in the mean values for the animals killed at $50 \mathrm{~d}$ of age. The efficiency with which the digested $\mathrm{N}$ intake was retained declined with age in both species.

The proportion of the metabolizable energy intake of the animals which was retained is shown in Table 7. In Expt I there was no significant difference between species in those animals killed at $30 \mathrm{~d}$ of age but significantly more $(P<0.0 \mathrm{I})$ 
Table 7. Effect of age and level of feeding on retention of the metabolizable energy intake in the empty body of lambs and pigs

\begin{tabular}{|c|c|c|c|c|c|}
\hline & & Exp & & & \\
\hline & $10-30$ & of age & $30-50$ & 1 of age & \\
\hline & $\begin{array}{l}\text { ad lib. } \\
\text { feeding }\end{array}$ & $\begin{array}{l}\text { Restricted } \\
\text { feeding }\end{array}$ & $\begin{array}{l}\text { ad lib. } \\
\text { feeding }\end{array}$ & $\begin{array}{l}\text { Restricted } \\
\text { feeding }\end{array}$ & $\begin{array}{c}\text { Expt 2, } \\
\text { 15-70 d of age }\end{array}$ \\
\hline Lambs & 0.547 & 0.488 & 0.550 & 0.534 & $0.55 \mathrm{I}$ \\
\hline Pigs & 0.570 & 0.506 & 0.616 & 0.597 & 0.434 \\
\hline $\begin{array}{c}\text { Least signific } \\
P=0.05\end{array}$ & & & & & 0.030 \\
\hline$P=0.01$ & & & & 60 & 0.046 \\
\hline
\end{tabular}

Table 8. Effect of age and level of feeding on mean live-weight gain ( $\mathrm{g} / \mathrm{d})$ of lambs and pigs

\begin{tabular}{|c|c|c|c|c|c|}
\hline & & Exp & & & \\
\hline & $10-30$ & d of age & $30-50$ & 1 of age & \\
\hline & $\begin{array}{l}\text { ad lib. } \\
\text { feeding }\end{array}$ & $\begin{array}{l}\text { Restricted } \\
\text { feeding }\end{array}$ & $\begin{array}{l}\text { ad lib. } \\
\text { feeding }\end{array}$ & $\begin{array}{l}\text { Restricted } \\
\text { feeding }\end{array}$ & $\begin{array}{c}\text { Expt 2, } \\
15-70 \mathrm{~d} \text { of age }\end{array}$ \\
\hline Lambs & 453 & 385 & $5 \circ 3$ & 404 & $372 \pm 16$ \\
\hline Pigs & 576 & $5 \times 9$ & 832 & 766 & $380 \pm 20$ \\
\hline Least signifi & & & & & \\
\hline$P=0.05$ & & 55 & & 7 & \\
\hline$P=0.01$ & & 6 & & & \\
\hline
\end{tabular}

Table 9. Effect of age and level of feeding on food conversion ratio

(kg milk dry matter/kg live-weight gain) of lambs and pigs

\begin{tabular}{|c|c|c|c|c|c|}
\hline & & Exp & & & \\
\hline & $10-30$ & of age & $30-50$ & d of age & \\
\hline & $\begin{array}{l}\text { ad lib. } \\
\text { feeding }\end{array}$ & $\begin{array}{l}\text { Restricted } \\
\text { feeding }\end{array}$ & $\begin{array}{c}\text { ad lib. } \\
\text { feeding }\end{array}$ & $\begin{array}{l}\text { Restricted } \\
\text { feeding }\end{array}$ & $\begin{array}{c}\text { Expt 2, } \\
\text { I 5-70 d of age }\end{array}$ \\
\hline Lambs & IIO & 103 & 139 & 147 & 130 \\
\hline Pigs & 102 & 93 & 143 & 126 & 96 \\
\hline Least signifi & & & & & \\
\hline$P<0.05$ & & 9 & & 15 & 10 \\
\hline$P<0.01$ & & 2 & & 24 & 15 \\
\hline
\end{tabular}


Table Io. Effect of age and level of feeding on protein $(N \times 6 \cdot 25)$, fat (diethyl ether extract), and mineral content of lambs and pigs

(Mean values with their standard errors for groups of three animals

(Expt I) and four animals (Expt 2))

\begin{tabular}{|c|c|c|c|c|c|}
\hline $\begin{array}{l}\text { Group } \\
\text { (see p. II5) }\end{array}$ & Animal & $\begin{array}{l}\text { Empty } \\
\text { body-wt* } \\
\text { (kg) }\end{array}$ & $\begin{array}{l}\text { Protein } \dagger \\
\text { (g) }\end{array}$ & $\begin{array}{l}\text { Fatt } \\
\text { (g) }\end{array}$ & $\underset{(\mathrm{g})}{\text { Mineral } \dagger}$ \\
\hline \multicolumn{6}{|c|}{ Expt I } \\
\hline Io d & $\begin{array}{l}\text { Lamb } \\
\text { Pig }\end{array}$ & $\begin{array}{l}7.2 \pm 0.07 \\
3.7 \pm 0.05\end{array}$ & $\begin{array}{c}1357 \pm 15 \\
539 \pm 8\end{array}$ & $\begin{array}{l}580 \pm 69 \\
245 \pm 21\end{array}$ & $\begin{array}{l}277 \pm 8 \\
106 \pm 4\end{array}$ \\
\hline \multirow[t]{4}{*}{$30 \mathrm{~d}$} & Lamb AL & $\begin{array}{l}16.8 \pm 0.2 \\
(25 \pm 1.4)\end{array}$ & $\begin{array}{c}2934 \pm 54 \\
(63)\end{array}$ & $\begin{array}{c}3292 \pm 19 \\
(108)\end{array}$ & $\begin{array}{c}654 \pm 23 \\
(15)\end{array}$ \\
\hline & Lamb R & $\begin{array}{l}16 \cdot 6 \pm 0 \cdot 1 \\
(29 \pm 2 \cdot 3)\end{array}$ & $\begin{array}{c}2965 \pm I 6 \\
(55)\end{array}$ & $\begin{array}{c}2634 \pm 79 \\
(7 \mathrm{I})\end{array}$ & $\begin{array}{c}649 \pm 6 \\
(13)\end{array}$ \\
\hline & Pig AL & $\begin{array}{l}15 \cdot 1 \pm 0 \cdot 1 \\
(22 \pm 0 \cdot 7)\end{array}$ & $\begin{array}{c}2229 \pm 37 \\
\quad(77)\end{array}$ & $\begin{array}{c}3167 \pm 270 \\
(\mathrm{r} 33)\end{array}$ & $\begin{array}{c}405 \pm 8 \\
(14)\end{array}$ \\
\hline & Pig R & $\begin{array}{l}14 \cdot 9 \pm 0 \cdot 3 \\
(23 \pm 2 \cdot 0)\end{array}$ & $\begin{array}{c}2341 \pm x 6 \\
(78)\end{array}$ & $\begin{array}{c}2390 \pm 154 \\
(93)\end{array}$ & $\begin{array}{l}415 \pm 4 \\
(13)\end{array}$ \\
\hline \multirow[t]{4}{*}{$50 \mathrm{~d}$} & Lamb AL & $\begin{array}{l}25 \cdot 7 \pm 0 \cdot I \\
(20 \pm 1 \cdot 0)\end{array}$ & ${ }_{(64)}^{4217 \pm 30}$ & $\begin{array}{c}6694 \pm 182 \\
(170)\end{array}$ & $\begin{array}{l}902 \pm 6 \mathrm{I} \\
\text { (I2) }\end{array}$ \\
\hline & Lamb $\mathbf{R}$ & $\begin{array}{l}25.8 \pm 0.4 \\
(26 \pm 4 \cdot 0)\end{array}$ & $\underset{(52)}{4318 \pm 56}$ & $\begin{array}{c}6237 \pm 625 \\
\quad(139)\end{array}$ & $\underset{(13)}{991 \pm 51}$ \\
\hline & Pig AL & $\begin{array}{l}32 \cdot 3 \pm 0 \cdot 1 \\
(21 \pm 0 \cdot 3)\end{array}$ & $\begin{array}{c}4273 \pm 40 \\
(97)\end{array}$ & $\begin{array}{c}10404 \pm 264 \\
(345)\end{array}$ & $\begin{array}{c}907 \pm 4 \\
(24)\end{array}$ \\
\hline & Pig R & $\begin{array}{l}32 \cdot 0 \pm 0.2 \\
(25 \pm 0.6)\end{array}$ & $\begin{array}{c}4766 \pm 5 I \\
(97)\end{array}$ & $\begin{array}{l}8307 \pm 108 \\
\quad(237)\end{array}$ & $\begin{array}{c}980 \pm 19 \\
(23)\end{array}$ \\
\hline \multicolumn{6}{|c|}{ Expt 2} \\
\hline $16 \mathrm{~d}$ & $\begin{array}{l}\text { Lamb } \\
\text { Pig }\end{array}$ & $\begin{array}{l}9.2 \pm 0.2 \\
3.5 \pm 0.3\end{array}$ & $\begin{array}{r}1644 \pm 42 \\
518 \pm 43\end{array}$ & $\begin{array}{l}855 \pm 77 \\
210 \pm 26\end{array}$ & $\begin{array}{l}328 \pm 10 \\
118 \pm 8\end{array}$ \\
\hline \multirow[t]{2}{*}{$70 \mathrm{~d}$} & Lamb & $\begin{array}{l}30.2 \pm 0.6 \\
(58 \pm 3.4)\end{array}$ & $\begin{array}{c}5490 \pm 43 \\
(66)\end{array}$ & $\begin{array}{c}6728 \pm 350 \\
(101)\end{array}$ & $\begin{array}{l}\text { II I I } \pm 27 \\
\quad(14)\end{array}$ \\
\hline & Pig & $\begin{array}{l}25 \cdot 6 \pm 0 \cdot 2 \\
(6 \mathrm{r} \pm 3 \cdot 4)\end{array}$ & $\begin{array}{c}4376 \pm 76 \\
(63)\end{array}$ & $\begin{array}{c}3110 \pm 133 \\
(48)\end{array}$ & $\underset{(\mathrm{r} 3)}{895 \pm 24}$ \\
\hline
\end{tabular}

AL, fed ad lib.; R, restricted to $20 \%$ of ad lib. intake.

* Values in parentheses are the number of days taken to achieve the various empty body-weight gains; e.g. in Expt $\mathrm{I}$ the lambs fed $a d \mathrm{lib}$. in the $30 \mathrm{~d}$ group took $25 \pm \mathrm{I} \cdot 4 \mathrm{~d}$ to reach $r 6.8 \mathrm{~kg}$ empty body-weight from an estimated $7.2 \mathrm{~kg}$ empty body-weight (mean weight of $10 \mathrm{~d}$ group); the lambs fed $a d$ lib. in the $50 \mathrm{~d}$ group took $20 \pm \mathrm{r} \cdot 0 \mathrm{~d}$ to reach $25.7 \mathrm{~kg}$ empty body-weight from an estimated $16.8 \mathrm{~kg}$ (mean weight of lambs fed ad lib. in $30 \mathrm{~d}$ group).

$\uparrow$ Values in parentheses are the estimated mean protein, fat or mineral deposited/d by the animals.

metabolizable energy was retained by the pigs killed at $50 \mathrm{~d}$ of age. In Expt 2 this situation was reversed and significantly more $(P<0.01)$ metabolizable energy was retained by the lambs.

\section{Live-weight gain and efficiency of food conversion}

Live-weight gain and food conversion ratio are given in Tables 8 and 9 respectively. In Expt $\mathrm{I}$ the pigs grew significantly faster $(P<0.01)$ than the lambs but there was 
Table I1. Expts 1 and 2. Distribution of protein and fat (\%) in the empty body of the lambs and pigs

(Mean values with their standard errors for groups of twenty-three animals)

\begin{tabular}{|c|c|c|c|c|c|}
\hline Animal & Carcass* & Offal† & $\begin{array}{l}\text { Digestive } \\
\text { tract }\end{array}$ & Blood & Skin and wool \\
\hline \multicolumn{6}{|c|}{ Protein } \\
\hline $\begin{array}{l}\text { Lambs } \\
\text { Pigs }\end{array}$ & $\begin{array}{l}58 \cdot 2 \pm 0 \cdot 4 \\
81 \cdot 5 \pm 0.8\end{array}$ & $\begin{array}{l}6.5 \pm 0.2 \\
7.8 \pm 0.1\end{array}$ & $\begin{array}{l}3.4 \pm 0.04 \\
4.7 \pm 0.09\end{array}$ & $\begin{array}{l}5 \cdot 6 \pm 0.1 \\
6 \cdot 0 \pm 0.2\end{array}$ & $\begin{array}{c}26.3 \pm 0.6 \\
-\end{array}$ \\
\hline \multicolumn{6}{|c|}{ Fat (diethyl ether extract) } \\
\hline $\begin{array}{l}\text { Lambs } \\
\text { Pigs }\end{array}$ & $\begin{array}{l}81 \cdot 7 \pm 0.4 \\
95.6 \pm 0.4\end{array}$ & $\begin{array}{r}11 \cdot 7 \pm 0.3 \\
3.3 \pm 0.2\end{array}$ & $\begin{array}{l}I \cdot 2 \pm 0.04 \\
I \cdot I \pm 0.05\end{array}$ & 二 & $5.4 \pm 0.1$ \\
\hline
\end{tabular}

* Lambs, including head, hooves and kidneys; pigs, including head, ears, hooves, tail, kidneys, skin and bristles.

$\dagger$ Tongue, trachea, diaphragm, liver, lungs, heart, pancreas, spleen, reproductive organs, omental fat, mesenteric fat, perinephric fat, superficial blood vessels and connective tissue.

little difference in rate of gain during Expt 2. In Expt I there was no significant difference in food conversion ratio ( $\mathrm{kg}$ dry matter of milk/kg live-weight gain) between the lambs and pigs fed $a d$ lib., but the pigs restricted in intake had a lower conversion ratio $(P<0.05)$ than the lambs similarly treated. In Expt 2 food conversion ratio was also lower $(P<$ o.or $)$ for the pigs than for the lambs.

\section{Composition of the live-weight gain}

The protein, fat and mineral content of the animals at slaughter and the daily deposition of protein, fat and minerals are given in Table Io. In Expt $\mathrm{I}$ the significant difference $(P<0.0 \mathrm{I})$ in daily live-weight gain between the lambs and pigs (Table 8 ) was associated throughout with differences in protein and fat deposition. The daily deposition of protein, fat and minerals increased with age in the pigs but only the deposition of fat increased with age in the lambs. A $20 \%$ restriction in voluntary food intake reduced the daily deposition of both protein and fat in the lambs but in the pigs a similar restriction in food intake reduced only the amount of fat deposited daily. In Expt 2 the amount of protein and minerals deposited daily was similar in the lambs and pigs, but an additional $53 \mathrm{~g}$ fat/d was laid down by the lambs.

\section{Distribution of protein and fat in the empty body of the animals}

There was no marked variation with age or level of feeding in the distribution of protein or fat within either species. The mean values for the distribution of protein and fat shown in Table $I$ includes therefore all animals in Expts $I$ and 2 irrespective of age or level of intake. The main difference between the species occurred in the distribution of protein in the carcass. A mean value of $81.5 \%$ of the protein of the pigs appeared in the carcass compared with less than $60 \%$ for the lambs. This was because $25-30 \%$ of the protein contained in the empty body of the lambs was stored in the skin and wool. 'The percentage of protein appearing in the 'offal', alimentary canal or blood of the two species was not greatly different. 
The distribution of fat also varied between species. A greater percentage of fat was stored in the carcasses of the pigs $(95.6 \%)$ than in the carcasses of the lambs $(81.7 \%)$. This was due partly to the fat contained in the skin and wool of the lambs, and partly to the presence of a greater percentage of fat in the offal of the lambs, a mean value of I I. $7 \%$ being recorded for the lambs compared with $3.3 \%$ for the pigs.

\section{DISCUSSION}

Meyer \& Nelson (1963) concluded from their species comparison that the capacity to ingest food was the most important single factor influencing efficiency of food utilization. This was the aspect of nutritional efficiency which differed most between the lambs and pigs in this study. Davies, Widdowson \& McCance (1964) found that the daily intake of energy of the pig during the period when it is doubling its birth weight is also considerably greater (two to three times) than that of the rat, rabbit, calf or man.

The higher voluntary food intake of the pigs was probably associated with a higher maintenance requirement and a higher relative food capacity, i.e. the ability to consume proportionally more food above maintenance than the lamb. Guilbert \& Loosli (r949) and Kleiber (196I) have presented evidence that the maximum intake of energy per $\mathrm{kg}$ live weight ${ }^{0.75}$ of small and large animals is related to their basal metabolism, and Blaxter, Wainman \& Davidson (1966) found that sheep with a high maintenance requirement ate more than those with a low one. It seems that the maintenance requirement of the pigs in this study was greater than that of the lambs. Thus, when the two species were fed at the same level of energy intake (Expt 2), total live-weight gain was similar but the daily deposition of fat by the pig was much less than that by the lambs (Table 10). It is possible that this was due to the lamb's more efficient use of metabolizable energy for maintenance. However, the efficiency of utilization of metabolizable energy for maintenance appears to be similar in the two species - thus the Agricultural Research Council (1967) quotes values of $81 \%$ for pigs and Walker \& Jagusch (1967) obtained identical values for milk-fed lambs. Fowler (1967) has reviewed the effect of nutrition on the relationship of body components in the sheep and pig and has quoted convincing evidence that, at any stage of growth, food given in excess of that required for maintenance and fat-free body growth will be converted into body lipid. By this reasoning the maintenance requirement of the pigs in Expt 2 was higher than that of the lambs. Similarly, in Expt I, this was probably the main reason for the greater voluntary intake by the pigs.

The results presented by Guilbert \& Loosli (1949) and Meyer \& Nelson (I963) indicate that the relative food capacity of pigs is greater than that of ruminant sheep but a comparison is made difficult by different diets and microbial $v$. enzymic digestion. Black (1971) has calculated that energy losses associated with ruminal fermentation of a high-quality diet are $20 \%$ greater than those recorded for enzymic digestion in the lower tract. Differences of this size would account for most of the disparity between sheep and pigs observed by Meyer $\&$ Nelson (1963). In the present experiment rumen fermentation was avoided and the higher voluntary intake of energy 
by the pigs in Expt I (Table 2) may have also been associated with differences in relative food capacity. Thus a $20 \%$ restriction in voluntary intake in the lamb reduced both protein and fat deposition/d, but a similar restriction in the pig only reduced fat deposition/d (Table ro).

The difference in voluntary food intake between the lambs and pigs in Expt $I$ is reflected in the growth rates obtained. The actual growth rate of the lambs exceeded that of the pigs only in the early stages of the experiment and their relative growth rate $\left(\mathrm{g} / \mathrm{kg}\right.$ live weight $\left.\mathrm{t}^{\cdot 75}\right)$ remained about 40 percentage units below that of the pigs throughout. Payne \& Wheeler (1968) quote weight gains of different species $/ \mathrm{kg}$ live weight ${ }^{0 \cdot 73}$. The highest rate was for the pigs, $76 \mathrm{~g} / \mathrm{kg}$ live weight ${ }^{0 \cdot 73}$, during the period before birth weight had quadrupled. The relative growth rate of the pigs in the present study was in excess of that rate even at much heavier weights ( $\mathrm{ro} 3 \mathrm{~g} / \mathrm{kg}$ live weight $t^{0.73}$ from Io to $3 \circ \mathrm{d}$ of age).

Although the voluntary intake of energy differed between the species, the utilization of the milk was similar. The digestible energy value of the milk was high and did not differ greatly for lambs or pigs. The values obtained for the lambs were similar to those reported by Walker \& Faichney (1964) for lambs fed on cow's milk.

The apparent digestibility of energy by the lambs and pigs was not affected by age or level of feeding. This is in agreement with the results of Jagusch \& Mitchell (197I) for milk-fed lambs and with those of Reid \& Tyrrell (1964) for pigs given dry diets. The metabolizable energy content of the milk was also similar for the lambs and pigs although it was significantly higher for the lambs in Expt I (Table 5). Again, level of intake had no significant effect on the metabolizable energy value of the milk, which is in agreement with the findings of Walker \& Jagusch (1967) for lambs and with those of Reid and Tyrrell (1964) for pigs. The apparent digestibility of $\mathrm{N}$ was also high for both species although it was significantly greater for the pigs in both experiments. It seems likely that the true digestibility of millk was close to $100 \%$ in both species and that the small differences in apparent digestibility were associated with differences in metabolic faecal $\mathrm{N}$ excretion.

The results of this study show that the efficiency of food conversion by the nonruminant lamb is high and not greatly different from that of the pig. However, restriction of food intake below ad lib. levels significantly improved food conversion efficiency in the pig but had no significant effect in the lamb (Table 9). This was probably due to the fact that the ratio of protein to fat deposited remained the same in the lamb but was increased in the pig (Table ro). This hypothesis is in agreement with Oslage \& Fliegel (1965), who estimated that the efficiency of utilization of metabolizable energy for growth in pigs decreased as the deposition of fat relative to protein increased.

This work was carried out during the tenure of an Australian Meat Research Committee Senior Studentship while on leave from the Victorian Department of Agriculture. The author is indebted to Dr G. R. Pearce, School of Agriculture, University of Melbourne, for advice throughout, to Mr R. Thomas and Mr D. Whitfield, School of Agriculture, University of Melbourne, for assistance in the care 
of the experimental animals and to Mr R. Jardine, Victorian Department of Agriculture for statistical advice.

The work was financed by the Australian Meat Research Committee, the Australian Wool Board, and the Reserve Bank of Australia (Rural Credits Development Fund).

\section{REFERENCES}

Agricultural Research Council (1965). The Nutrient Requirements of Farm Livestock No. 2, Ruminants. London: Agricultural Research Council.

Agricultural Research Council (1967). The Nutrient Requirements of Farm Livestock No. 3, Pigs. London: Agricultural Research Council.

Black, J. L. (197r). Br. $\mathscr{~ I . ~ N u t r . ~ 2 5 , ~} 3$ I.

Blaxter, K. L. (1968). Proc. 2nd World Conf. Anim. Prod. Urbana, Illinois: American Dairy Science Association.

Blaxter, K. L., Wainman, F. W. \& Davidson, J. L. (1966). Anim. Prod. 8, 75.

Davies, J. S., Widdowson, E. M. \& McCance, R. A. (1964). Br. F. Nutr. 18, 385 .

Fowler, V. R. (1967). In Growth and Development of Mammals (Proceedings, 14th Easter School in Agricultural Science, Nottingham) p. ${ }_{55}$ [G. A. Lodge and G. E. Lamming, editors]. London: Butterworth.

Guilbert, H. R. \& Loosli, J. K. (1949). Congr. int. Zootech. v Paris p. 167.

Jagusch, K. T. \& Mitchell, R. M. (197I). N.Z. Fl agric. Res, 14, 434.

Kleiber, M. (196r). The Fire of Life. New York: John Wiley.

Meyer, J. H. \& Nelson, A. O. (x963). F. Nutr. 80, 343.

Oslage, H. J. \& Fliegel, H. (1965). Publs Eur. Ass. Anim. Prod. no. II, p. 297.

Payne, P. R. \& Wheeler, E. F. (I968), Proc. Nutr. Soc. 27, 129.

Reid, J. T. \& Tyrrell, H. F. (I964). Cornell Nutr. Conf. p. 25.

Walker, D. M. \& Faichney, G. J. (1964). Br. F. Nutr. 18, I87.

Walker, D. M. \& Jagusch, K. T. (1967). Publs Eur. Ass. Anim. Prod. no. I2, p. 187. 